\title{
Arsenic and Copper Residues in Waterbirds and Their Food Down Inlet from the Island Copper Mill
}

\author{
K. Vermeer and J. A. J. Thompson \\ Institute of Ocean Sciences, P.O. Box 6000, Sidney, BC, V8L 4B2, Canada
}

Since 1971, Island Copper Mine has been operating an open-pit mine, mainly for copper on the north shore of Rupert Inlet. Rupert Inlet is the most easterly inlet of Quatsino sound on northern Vancouver Island, British Columbia (Fig. 1). The ore body was estimated to contain 250 million tons of reserves. Mining is proposed to be continued until 1996, at which time the reserves will have been depleted (Island Copper Mine, pers. comm.). The mine processes daily 41,000 tons of ore, containing on average 0.52\% copper (Waldichuk and Buchanan 1980). Mine tailings are discharged into Rupert Inlet at a depth of $50 \mathrm{~m}$. The tailings now cover the bottom of Rupert Inlet (originally $100 \mathrm{~m}$ deep), as well as much of that of Holberg Inlet and part of eastern Quatsino sound, past Quatsino Narrows (Fig. 1): The tailings contain an average of about $700 \mathrm{mg} / \mathrm{kg}^{-1}$ copper and $5 \mathrm{mg} / \mathrm{kg}^{-1}$ arsenic (Thompson and Paton 1975). The concentrations of the same metals in natural sediments of Rupert Inlet are $44 \mathrm{mg} / \mathrm{kg}^{-1}$ copper and $5 \mathrm{mg} / \mathrm{kg}^{-1}$ arsenic (Waldichuk and Buchanan 1980). As chemical data were lacking, a pilot study was initiated in March 1976 to determine arsenic and copper residues in tissues of birds in Quatsino sound and connecting inlets. After finding elevated arsenic residues in bird livers in 1976, waterbirds and their food chain were further investigated for arsenic and copper from october 1981 through March 1982. The results of the 1976 and 1981-82 analyses are presented here.

\section{MATERIALS AND METHODS}

Beach deposit and algae (Ulva and Enteromorpha sp.), blue mussels (Mytilus edulis) and shore crabs (Hemigrapsis sp.) were collected at beach sites throughout Quatsino sound downstream from the mine site (Fig. 1). Western Grebes (Aechmophorus occidentalis), Glaucous-winged Gulls (Larus glaucescens), Marbled Murrelets (Synthliboramphus

Send reprint requests to Kees Vermeer at the above address. 


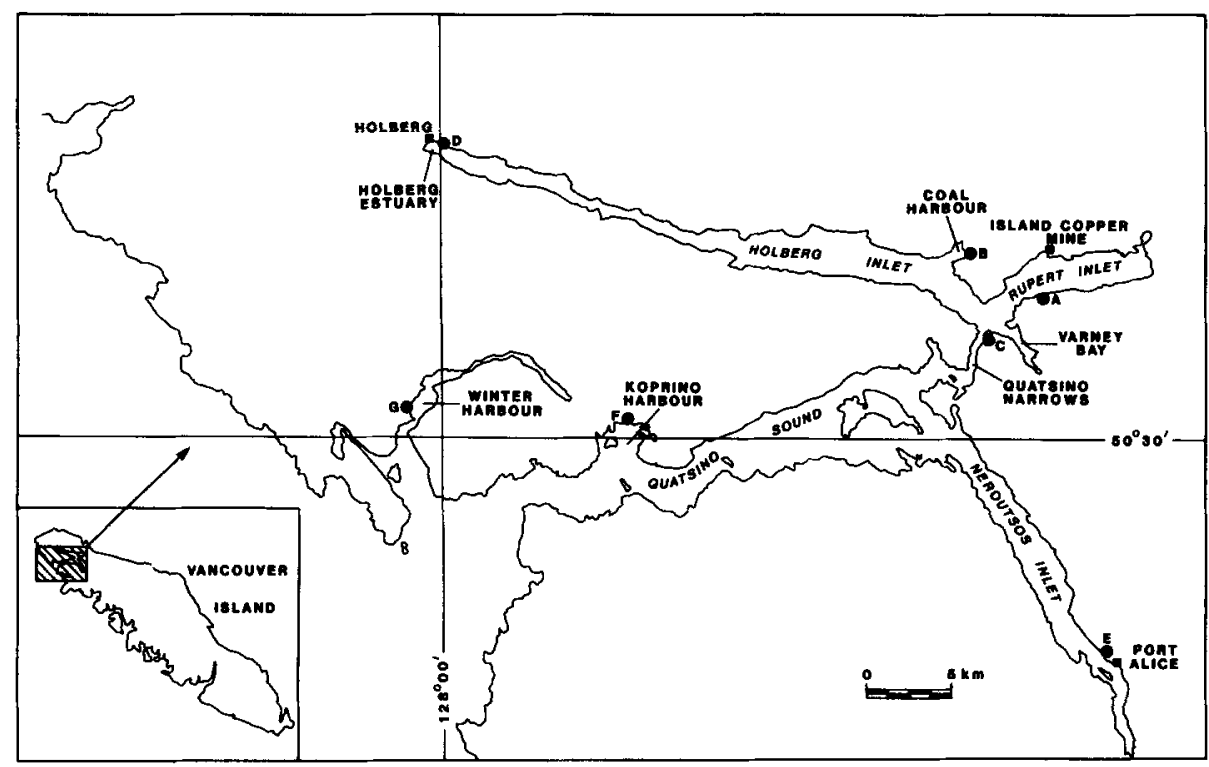

Figure 1. Location of sampling stations throughout Quatsino sound and inlets.

antiguus), American wigeon (Anas mareca), Mallards (A. platyrhynchos), and Buffleheads (Bucephala albeola) were collected with a shotgun (under permit) throughout Rupert and Holberg inlets, Varney Bay, Quatsino Narrows and Koprino Harbour in March 1976 and from October 1981 through March 1982. The bird species collected were either common or numerous in Quatsino sound.

Bird livers and stomachs were removed immediately after collection, and those tissues were examined to ensure that no shot fragments remained in the samples for analysis. Bird livers and stomachs, algae, mussels, and crabs were frozen within two hours after collection. In the laboratory, bird livers, beach deposit, Ulva, Enteromorpha and whole mussels and crabs, and identifiable food items of birds were analyzed for arsenic and copper residues. The 1976 samples were analyzed by the ontario Research Foundation at Mississauga, Ontario, and those of 1981-82 were analyzed by Barringer Magenta Ltd. of Rexdale, Ontario. For the 1976 and 1981-82 samples, copper was determined by flameless atomic absorption. In 1976 arsenic was determined by silver dithiocarbamate complexation (Penrose et al. 1975). In the latter study arsenic was determined after digestion in a nitric/perchloric/ sulfuric acid mixture followed by hydride-atomic 
absorption analysis of the digest (Smith et al. 1977). Copper and arsenic (only in the 1981-82 samples) residues were checked against National Bureau standard (NBS) bovine liver, oyster tissue and citrus leaves. All recoveries were within certified limits. The precision of the analytical procedures in 1981-82 was also checked against 5 blind replicate bird liver samples which showed coefficients of variation of $<20 \%$ for copper and arsenic. In case of arsenic in beach deposit samples, the control used was a standard soil (CANMET, Government of Canada), and the coefficient of variation was $1 \%$.

\section{RESULTS AND DISCUSSION}

Arsenic was highest in beach deposit, but did not show a gradient (except for Ulva) in Enteromorpha, Mytilus edulus and Hemigrapsis from Rupert Inlet to Winter Harbour (Table 1). Copper was highest in beach deposit and Hemigrapsis. Hemigrapsis could have obtained high residues by their feeding on detritus in copper contaminated beach deposit. Copper was generally higher in beach deposit, algae, mussels and crabs in locations near (Rupert Inlet, Coal Harbour, Quatsino Narrows) than at those farther (Port Alice, Koprino and Winter Harbour) from the mine. The relatively high copper concentrations observed in beach deposit, Ulva and Hemigrapsis in a backwater at Quatsino Narrows may relate to extensive tidal activity there. strong tidal currents were observed to stir up mine tailings in and near the entrances of the Narrows (Vermeer pers. observ.).

When Island Copper Mine began operating, the mine analyzed zooplankton, clams, crabs and fish from stations in Rupert Inlet and adjacent waters for arsenic and copper. Those elements were observed to be evenly distributed throughout the system (Ellis 1973). Copper, however, was elevated in intertidal fishes at stations nearest to the mine outfall. Arsenic in Dungeness Crabs (Cancer magister), was significantly less ( $t=12.5$, $p<0.001)$ in predischarge $(n=6$, average and SD $0.11 \pm 0.08 \mathrm{mg} \mathrm{kg}{ }^{-1}$ ) in June 1971 than in post discharge samples from the various stations $(n=6$, average and SD $5.5 \pm 2.7 \mathrm{mg} \mathrm{kg}^{-1}$ in June 1972). Arsenic in Dogfish Shark (Squalus acanthius) ( $\mathrm{n}=3$, average and SD $0.19 \pm 0.11$ and $\mathrm{n}=4$, average and SD $3.63 \pm 1.08 \mathrm{mg} \mathrm{kg} \mathrm{kg}^{-1}$ in June 1971 and 1972, respectively) showed a similar trend ( $t=12.5$, p $<0.001)$. Ellis (1973) ascribed these differences to results from a change in chemical analysis over those years. However, arsenic in sculpins (oligocottus maculosus) and some other intertidal fishes remained similar between predischarge $(n=6$, average and SD $\left.0.59 \pm 0.56 \mathrm{mg} \mathrm{kg}^{-1}\right)$ and post discharge ( $n=7$, average and SD $0.53 \pm 0.17 \mathrm{mg} \mathrm{kg}^{-1}$ ) samples, suggesting that those different results could not be attributed to different 
Table 1. Comparison of arsenic and copper residues in beach deposit, algae (Enteromorpha and alva sp.), mussels (Mytilus edulis) and shorecrabs (Hemigrapsis sp.) down inlet from the Island Copper Mine in Quatsino Sound, October 1981 - March 1982). Beach deposits were pooled grab samples consisting of three separate samples each, and tissue samples consisted of 10 items each.

Sample station

numbers and

locations
Metal residues in $\mathrm{mg} \mathrm{kg}^{-1}$ wet weight

Beach

Deposit Ulva Enteromorpha Mytilus Hemigrapsus edulis

Arsenic

$\begin{array}{llllll}\text { A Rupert Inlet } & 2.7 & 1.3 & 0.38 & 0.23 & 0.21 \\ \text { B Coal Harbour } & 2.7 & 0.41 & 0.44 & 0.23 & 0.37 \\ \text { C Quatsino Narrows } & 4.8 & 0.68 & 0.28 & 0.22 & 0.22 \\ \text { D Estuary at Holberg } & 3.2 & - & 0.17 & - & - \\ \text { E Port Alice } & 14.6 & 0.68 & 0.18 & 0.36 & - \\ \text { F Koprino Harbour } & 4.9 & 0.26 & 0.36 & 0.04 & 0.65 \\ \text { G Winter Harbour } & 4.1 & 0.39 & 0.12 & 0.45 & 0.26\end{array}$

Copper

\begin{tabular}{llllll} 
A Rupert Inlet & 19.6 & 5.9 & 4.9 & 3.1 & 22.1 \\
B Coal Harbour & 30.4 & 1.0 & 6.5 & 1.4 & 15.8 \\
C Quatsino Narrows & 37.7 & 9.2 & 4.6 & 1.7 & 25.0 \\
D Estuary at Holberg & 26.5 & - & 1.1 & - & - \\
E Port Alice & 11.8 & 0.88 & 0.94 & 1.8 & - \\
F Koprino Harbour & 19.9 & 1.8 & 1.5 & 0.93 & 16.9 \\
G Winter Harbour & 10.4 & 0.64 & 0.49 & 0.97 & 13.4 \\
\hline
\end{tabular}

Table 2. Comparison of arsenic and copper residues in livers of waterbirds down inlet from the Island Copper Mine in Quatsino Sound, March 1976 and October 1981 - March 1982.

\begin{tabular}{|c|c|c|c|c|}
\hline \multirow[b]{2}{*}{ Species } & \multirow{2}{*}{$\begin{array}{c}\text { Year of } \\
\text { collection }\end{array}$} & \multicolumn{3}{|c|}{$\begin{array}{l}\text { Average metal residues in } \mathrm{mg}^{\mathrm{kg}^{-1}} \\
\text { wet weight } \pm \mathrm{SD} \\
\end{array}$} \\
\hline & & birds & Arsenic & Copper \\
\hline $\begin{array}{l}\text { Western Grebe } \\
\text { Western Grebe } \\
\text { Glaucous-winged Gull } \\
\text { Glaucous-winged Gull } \\
\text { Marbled Murrelet } \\
\text { Marbled Murrelet } \\
\text { American Wigeon } \\
\text { Mallard } \\
\text { Bufflehead }\end{array}$ & $\begin{array}{r}76 \\
81-82 \\
76 \\
81-82 \\
76 \\
81-82 \\
81-82 \\
81-82 \\
81-82\end{array}$ & $\begin{array}{r}6 \\
6 \\
6 \\
6 \\
6 \\
25 \\
14 \\
17 \\
20\end{array}$ & $\begin{array}{l}1.11 \pm 0.70 \\
0.08 \pm 0.09 \\
1.63 \pm 1.52 \\
0.14 \pm 0.14 \\
3.23 \pm 1.37 \\
0.78 \pm 0.68 \\
0.09 \pm 0.06 \\
0.14 \pm 0.23 \\
0.22 \pm 0.15\end{array}$ & $\begin{array}{r}6.2 \pm 2.9 \\
5.3 \pm 1.0 \\
6.1 \pm 0.8 \\
5.6 \pm 0.7 \\
7.1 \pm 3.9 \\
6.3 \pm 0.8 \\
31.5 \pm 13.0 \\
22.6 \pm 9.8 \\
10.8 \pm 3.8\end{array}$ \\
\hline
\end{tabular}

analytical procedures. Higher arsenic in Dungeness Crabs and Dogfish Shark at post discharge stations suggest bioaccumulation of this element. 
Table 3. Comparison of arsenic and copper residues in food found in stomachs of Marbled Murrelets, Mallards and Bufflehead, and in silt in stomachs of Mallards and Bufflehead down inlet from the Island Copper Mine in Quatsino Sound, winter 1981-82.

\begin{tabular}{|c|c|c|c|}
\hline \multirow[b]{2}{*}{ Species } & \multirow{2}{*}{$\begin{array}{l}\text { o. bird stomachs } \\
\text { mpled (pooled) }\end{array}$} & \multicolumn{2}{|c|}{$\begin{array}{c}\text { Average residues in } \mathrm{mg} \mathrm{kg}^{-1} \\
\text { wet weight }\end{array}$} \\
\hline & & Arsenic & Copper \\
\hline \multicolumn{4}{|l|}{ Marbled Murrelet } \\
\hline sculpin & 1 & 0.08 & 1.1 \\
\hline Herring & 5 & 0.05 & 1.1 \\
\hline Herring & 4 & 0.07 & 2.6 \\
\hline Euphausiids & 2 & 0.06 & 1.0 \\
\hline Euphausiids & 4 & 0.15 & 7.7 \\
\hline \multicolumn{4}{|l|}{ American Wigeon } \\
\hline Navicula sp. & 3 & 0.24 & 1.4 \\
\hline Navicula sp. & 4 & 0.20 & 1.3 \\
\hline Enteromorpha sp. & 2 & 0.05 & 1.4 \\
\hline Enteromorpha sp. & 2 & 0.03 & 0.35 \\
\hline$\overline{\text { Silt }}$ & 5 & 1.1 & 5.5 \\
\hline silt & 3 & 1.8 & 7.7 \\
\hline \multicolumn{4}{|l|}{ Mallard } \\
\hline Littorina scutulata & 1 & 0.09 & 2.9 \\
\hline Littorina scutulata & 3 & 0.01 & 1.5 \\
\hline Mytilus edulus & 1 & 0.07 & 0.81 \\
\hline Balanus glandula & 2 & 0.29 & 1.2 \\
\hline$\overline{\text { silt }}$ & 1 & 0.29 & 30.7 \\
\hline silt & 3 & 1.7 & 6.2 \\
\hline \multicolumn{4}{|l|}{ Bufflehead } \\
\hline Unid. crabs & 4 & 0.31 & 7.2 \\
\hline Polychaetes & 3 & 0.30 & 11.4 \\
\hline Littorina scutulata & 3 & 0.60 & 2.6 \\
\hline Littorina scutulata & 2 & 0.55 & 1.8 \\
\hline$\overline{\text { silt }}$ & 3 & 1.4 & 21.4 \\
\hline silt & 2 & 0.53 & 5.6 \\
\hline
\end{tabular}

Arsenic in livers of Marbled Murrelets was significantly higher $(t=4.19, p<0.001)$ in 1976 than in 1981-82. Of all birds, Marbled Murrelets had the highest arsenic levels (Table 2). Marbled Murrelets were chiefly observed feeding upon Pacific Herring (Clupea harengus) and euphausiids (Thysanoessa spinifera and Euphausia pacifica). Arsenic in those organisms ranged from 0.03 to $0.15 \mathrm{mg} \mathrm{kg}^{-1}$ (Table 3).

American wigeon fed mostly on algae (Enteromorpha, Navicula and Ulva sp.) and Mallards on snails (Littorina scutulata, L. sitkana, Lammaria, Margarites, Nassarius and Turbonilla spp. and barnacles (Balanus glandula) in quatsino Sound (Vermeer unpubl. data). Much silt and gravel were also observed to be ingested by those birds. Since those foods and the silt in bird stomachs were relatively high in copper (Table 3), American Wigeon and Mallards could have obtained that metal from their food as well as from ingested silt. 
No trend was observed in arsenic and copper residues in livers of birds collected at any distance from the Island Copper Mine, suggesting either that birds fed throughout Quatsino Sound and/or that arsenic and copper were widely distributed throughout the sound.

American wigeon and Mallards are hunted and consumed. Although copper levels were higher in livers of those two species than in other birds, there need be no concern for human health, as copper in breast muscle, the tissue which is eaten, generally contains lower metal residues than liver.

\section{REFERENCES}

Ellis DV 1973. Appendix No. 3. Island Cooper Mine monitoring program. Summary report initial production year. oct. 1971-Sept. 1972. Environmental control program Island Copper Mine. Univ. British Columbia, Vancouver, British Columbia.

Penrose WR, Black R, Hayward MJ (1975) Limited arsenic dispersion in seawater sediments, and biota near a continuous source. $J$ Fish Res Board Can 32:1275-1281.

Smith RG, Van Loon JC, Knechtel JR, Fraser JL, Pitts AE, Hodges AE (1977) A sample and rapid hydride generation-atomic absorption method for the determination of arsenic in biological, environmental and geological samples. An Chim Acta 93:61-67.

Thompson JAJ, Paton DW (1975) Chemical delineation of a submerged mine tailings plume in Rupert and Holberg inlets. BC Fish Mar Serv Tech Rept No 506.

Waldichuk M, Buchanan RJ (1980) Significance of environmental changes due to mine waste disposal into Rupert Inlet. Fisheries and oceans, Vancouver, British Columbia.

Received October 14, 1991; accepted December 2, 1991. 